\title{
ANALISIS JENIS PLASMODIUM PENYEBAB MALARIA TERHADAP HITUNG JUMLAH TROMBOSIT
}

Ni Nengah Yunita Artini, Erlin Yustin Tatontos, Urip

Jurusan Analis Kesehatan, Poltekkes Kemenkes Mataram, Indonesia.

\begin{tabular}{l}
\hline Article Info \\
\hline Article history: \\
Received Jan $23^{\text {th }}, 2019$ \\
Revised Jan $31^{\text {st }}, 2019$ \\
Accepted Feb $21^{\text {st }}, 2019$ \\
\hline
\end{tabular}

\section{Keyword:}

Plasmodium type

Platelet count

Malaria

\begin{abstract}
Malaria is a parasitic infectious disease caused by Plasmodium in erythrocytes. Malaria is caused by the protozoa of the genus Plasmodium which is transmitted by female Anopheles mosquitoes, Malaria affects almost all components of blood, and thrombocytopenia is one of the haematological disorders encountered, and has received much attention in the literature scientific. This study was to determine the effect of Plasmodium type on malaria infection on platelet count. This study was observational analytic with a case control approach, the number of samples using saturated samples, sampling techniques with accidental sampling, namely taking cases or respondents who happened to exist or were available somewhere according to the context of the study. The results of the analysis from 32 samples of patients obtained 12 positive samples, namely 4 patients infected with Plasmodium falciparum with an average platelet count of 86,250 cells / $\mu$ l blood, 2 patients infected with Plasmodium vivax with a mean platelet count of 73,000 cells / $\mu \mathrm{l}$ blood, and 6 patients infected with Plasmodium mix with a mean number 88,700 cells / $\mu 1$ of blood platelets
\end{abstract}

Keywords: Plasmodium type, platelet count, Malaria

Copyright $\odot$ JurnalAnalisMedika Bio Sains All rights reserved.

\begin{abstract}
ABSTRAK
Malaria adalah penyakit infeksi parasit yang disebabkan oleh Plasmodium di dalam eritrosit, Penyakit malaria disebabkan oleh protozoa genus Plasmodium yang ditularkan oleh nyamuk Anopheles betina, Malaria mempengaruhi hampir semua komponen darah, dan trombositopenia merupakan salah satu kelainan hematologis yang ditemui, dan banyak mendapat perhatian di literatur ilmiah. Penelitian ini adalah untuk mengetahui pengaruh jenis Plasmodium penyebab infeksi malaria terhadap hasil hitung jumlah trombosit. Penelitian ini bersifat observasional analitik dengan pendekatan case control, jumlah sampel menggunakan sampel jenuh, teknik pengambilan sampel dengan Accidental Sampling yaitu mengambil kasus atau responden yang kebetulan ada atau tersedia di suatu tempat sesuai dengan konteks penelitian. Hasil analisis dari 32 sampel pasien didapatkan 12 sampel positif yaitu 4 pasien terinfeksi Plasmodium falciparum dengan rerata jumlah trombosit $86.250 \mathrm{sel} / \mu \mathrm{l}$ darah , 2 pasien terinfeksi Plasmodium vivax dengan rerata jumlah trombosit $73.000 \mathrm{sel} / \mu \mathrm{l}$ darah, dan 6 pasien terinfeksi Plasmodium mix dengan rerata jumlah trombosit $88.700 \mathrm{sel} / \mu \mathrm{l}$ darah.
\end{abstract}

Kata Kunci : Jenis Plasmodium, Jumlah Trombosit, Malaria

Copyright $@$ JurnalAnalisMedika Bio Sains

\section{Pendahuluan}

Malaria adalah penyakit infeksi parasit yang Penyakit malaria merupakan suatu penyakit disebabkan oleh Plasmodium di dalam eritrosit. infeksi yang memberikan morbiditas yang cukup 
tinggi di dunia dan merupakan penyebab mortalitas ketiga tertinggi di dunia. Walaupun di beberapa negara maju tidak dijumpai lagi infeksi malaria, tetapi lebih dari 106 negara di dunia masih menangani infeksi malaria ${ }^{4}$.

Penyakit malaria disebabkan oleh protozoa genus Plasmodium, yang ditularkan oleh nyamuk Anopheles betina, dan sudah dikenal sejak 3000 tahun yang lalu. Ada 4 jenis Plasmodium yang menyebabkan penyakit malaria pada manusia yaitu Plasmodium vivax, Plasmodium malariae, Plasmodium falciparum dan Plasmodium ovale ${ }^{2}$.

Malaria mempengaruhi hampir semua komponen darah, dan trombositopenia merupakan salah satu kelainan hematologis yang ditemui, dan banyak mendapat perhatian di literatur ilmiah. Infeksi Plasmodium dapat menyebabkan abnormalitas pada struktur dan fungsi trombosit. Beberapa mekanisme yang dipostulasikan sebagai penyebab trombositopenia diantaranya lisis dimediasi imun, sekuestrasi pada limpa dan gangguan pada sumsum tulang ${ }^{1}$.

Malaria dapat menyebabkan kelainan hemostatik yang dapat berupa asimptomatik trombositopenia. Trombosit dan produk aktivasinya terlibat dalam sekuestrasi dari eritrosit terinfeksi pada endotel kapiler dan venula, yang merupakan proses patologis malaria berat.

Tujuan penelitian ini adalah untuk mengetahui pengaruh jenis Plasmodium penyebab infeksi malaria terhadap hasil hitung jumlah trombosit.

Beberapa penelitian menghubungkan derajat trombositopenia dengan tingkat keparahan malaria. Penelitian Loly R.D Siagian, Mona Zubaidah, dan Riski Ayu Rimadani (2018) tentang hubungan derajat trombositopenia dengan malaria berat pada pasien malaria di Rumah Sakit Kanujoso Djatiwibowo Balikpapan, hasil penelitian ini menunjukan terdapat hubungan yang bermakna antara derajat trombositopenia dengan malaria berat dari 73 pasien sebanyak 17 pasien $(23,28 \%)$ mengalami malaria berat yang terdiri dari 10 pasien $(58,82 \%)$ dengan trombositopenia berat dan 7 pasien $(41,17 \%)$ dengan trombositopenia ringan sedang.

Penelitian Azhari Muslim (2015) tentang hubungan pemeriksaan hitung jumlah trombosit dan kadar hemoglobin pada infeksi malaria hasil penelitian ini menunjukan nilai rata-rata kadar hemoglobin pada penderita malaria adalah 8,96 gr/Dl. Nilai rata-rata jumlah trombosit adalah 113.000 trombosit/uL. Serta ada korelasi antara kadar hemoglobin dengan jumlah trombosit pada penderita malaria.

Data secara kuantitatif penurunan jumlah trombosit pada penderita berbagai jenis Plasmodium penyebab infeksi malaria seperti infeksi malaria tropika yang disebabkan oleh Plasmodium falciparum, malaria tertiana yang disebabkan oleh Plasmodium Vivax, malaria quartana disebabkan oleh Plasmodium malariae dan malaria pernisiosa di sebabkan oleh Plasmodium ovale belum pernah dilaporkan, karena itu perlu dilakukan penelitian mengenai 'Pengaruh jenis Plasmodium penyebab infeksi Malaria terhadap hasil hitung jumlah trombosit'.

\section{Metode Penelitian}

Penelitian ini merupakan penelitian Observasional analitik dengan pendekatan case control yaitu penelitian epidomologi analitik observasional yang menelah hubungan antara efek penyakit atau kondisi kesehatan tertentu dengan faktor risiko tertentu ${ }^{5}$. Dalam penelitian ini peneliti ingin mengetahui pengaruh 
jenis Plasmodium penyebab infeksi malaria terhadap hasil hitung jumlah trombosit. Pengumpulan data dan pengujian laboratoriumdalam penelitian ini dilaksanakan pada bulan april hingga bulan mei 2019.

Teknik pengambilan sambel yang digunakan dalam penlitian ini adalah Accidental Sampling yaitu enelitian yang dilakukan dengan mengambil kasus atau responden yang kebetulan ada ${ }^{3}$. Adapun sampel yang digunakan dalam penelitian, yaitu mahasiswa pasien yang dinyatakan positif alaria berdasarkan pemeriksaan mikroskopis di wilayan Kabupaten Lombok Barat dan bersedia menjadi responden dengan menandatangani informed concent. Besar sampel dilakukan denga cara sampling jenuh. Variabel dalam penelitian ini terdiri dari variabel bebas yaitu Plasmodium penyebab infeksi malaria, sedangkan variabel terikat yaitu hitung jumlah trombosit.

Dari data yang diambil adalah data primer dari pemeriksaan jenis Plasmodium penyebab malaria terhadap hitung jumlah trombosit. Data diperoleh disajikan dalam bentuk tabel kemudian dianalisa secara Deskriptif.

\section{Hasil Penelitian dan Pembahasan}

Penelitian yang telah dilakukan pada pemeriksaan sediaan malaria sebanyak 32 sampel yang terdiri dari 10 sampel di Puskesmas Meninting dan 22 sampel di Puskesmas Penimbung diperoleh hasil 12 sampel positif dari kedua Puskesmas kemudian dilakukan pemeriksaan jenis Plasmodium penyebab infeksi malaria. Hasil pemeriksaan jenis Plasmodium penyebab malaria terhadap hitung jumlah trombosit dapat dilihat pada tabel 4.1 dibawah ini.

Tabel 4.1 Hasil Pemeriksaan Jenis Plasmodium Penyebab Malaria TerhadapHitung Jumlah Trombosit

\begin{tabular}{|l|l|l|}
\hline \multicolumn{1}{|c|}{ Sampel } & \multicolumn{1}{|c|}{ Jenis Plasmodium } & \multicolumn{1}{c|}{ Stadium } \\
\hline 1 & Plasmodium falciparum & Skizon \\
\hline 2 & Plasmosium mix & Tropozoit \\
\hline 3 & Plasmodium falciparum & Gametosit \\
\hline 4 & Plasmosium mix & Tropozoit \\
\hline 5 & Plasmosium mix & Tropozoit \\
\hline 6 & Plasmosium mix & Tropozoit \\
\hline 7 & Plasmodium falciparum & Skizon \\
\hline 8 & Plasmosium mix & Tropozoit \\
\hline 9 & Plasmosium vivax & Tropozoit \\
\hline 10 & Plasmodium falciparum & Skizon \\
\hline 11 & Plasmodium vivax & Tropozoit \\
\hline 12 & Plasmosium mix & Tropozoit \\
\hline
\end{tabular}

Berdasarkan tabel 4.1 Data Hasil

Pemeriksaan Jenis Plasmodium Penyebab Malaria Terhadap Hitung Jumlah Trombosit didapatkan hasil pemeriksaan yaitu 4 Plasmodium Falciparum, 6 Plasmodium mix dan 2 Plasmodium Vivax dari 12 sampel yang diperiksa. Pada plasmodium falciparum terdiri 
Tabel 4.2 Data Hasil Pemeriksaan Jumlah Trombosit Sesuai Jenis Plasmodium Penyebab Infeksi

\begin{tabular}{|c|l|l|l|}
\hline No. & \multicolumn{1}{|c|}{ Jenis Plasmodium } & \multicolumn{1}{|c|}{$\begin{array}{c}\text { Rerata jumlah } \\
\text { trombosit }\end{array}$} & Interpretasi hasil \\
\hline 1. & P. falciparum & $\begin{array}{l}86.250 \mathrm{sel} / \mu \mathrm{l} \\
\text { darah }\end{array}$ & Rendah \\
\hline 2. & P. mix & $\begin{array}{l}73.000 \mathrm{sel} / \mu \mathrm{l} \\
\text { darah }\end{array}$ & Rendah \\
\hline 3. & P. vivax & $\begin{array}{l}88.700 \mathrm{sel} / \mu \mathrm{l} \\
\text { darah }\end{array}$ & Rendah \\
\hline
\end{tabular}

Tabel 4.2 data hasil pemeriksaan jumlah trombosit sesuai jenis plasmodium penyebab infeksi malaria didapatkan hasil rerata jumlah trombosit pada plasmodium falciparum adalah $86.250 \mathrm{sel} / \mu \mathrm{l}$ darah, plasmodium mix 73.000

\section{Kesimpulan}

Jenis Plasmodium penyebab infeksi malaria terhadap hitung jumlah trombosit didapatkan 3 Plasmodium yaitu Plasmodium falciparum, Plasmodium Vivax dan Plasmodium Mix.

Jumlah trombosit sesuai jenis Plasmodium penyebab infeksi malaria dengan rata-rata pada Plasmodium falciparum yaitu 86.250 sel/ $\mu$ l darah, pada Plasmodium Vivax didapatkan rata-rata jumlah trombosit adalah $73.000 \mathrm{sel} / \mu \mathrm{l}$ darah, sedangkan pada Plasmodium Mix didapatkan rata-rata jumlah trombosit 88.700 sel $/ \mu 1$ darah.

Hasil analisis dari 32 sampel pasien didapatkan 12 sampel positif yaitu 4 pasien terinfeksi Plasmodium falciparum dengan rerata jumlah trombosit $86.250 \mathrm{sel} / \mu \mathrm{l}$ darah , 2 pasien terinfeksi Plasmodium vivax dengan rerata jumlah trombosit $73.000 \mathrm{sel} / \mu \mathrm{l}$ darah, dan 6 pasien terinfeksi Plasmodium mix dengan rerata jumlah trombosit $88.700 \mathrm{sel} / \mu \mathrm{l}$ darah. $\mathrm{sel} / \mu \mathrm{l}$ darah dan plasmodium vivax $88.700 \mathrm{sel} / \mu \mathrm{l}$ darah, dari rerata jumlah trombosit didapatkan iterpretasi hasil yang rendah karena nilai normal trombosit 150.000 sampai $300.000 \mathrm{sel} / \mu \mathrm{l}$ darah,

\section{Daftar Pustaka}

1. Ivanna. (2013). hubungan antara derajat keparahan Malaria dengan jumlah trombosit pada pasien Malaria di RSU Bethesda Serukam Kabupaten Bengkayang.

2. Muslim, A. (2013). Hubungan pemeriksaan hitung jumlah trombosit dan kadar hemoglobin pada infeksi malaria.

3. Notoatmodjo, S. (2012). Metode Penelitian Kesehatan. Jakarta: Rineka Cipta.

4. Sari, A. (2017). Hubungan Derajat Keparahan Malaria dengan Jumlah Trombosit pada Pasien Rawal Inap di RSUP H . Adam Malik.

5. Sastroasmoro dan Ismail. (2006). DasarDasar Metodelogi Penelitian Klinis. Jakarta: Sagung Seto. 